\title{
The psychology of animal companionship: Some ancient and modern views
}

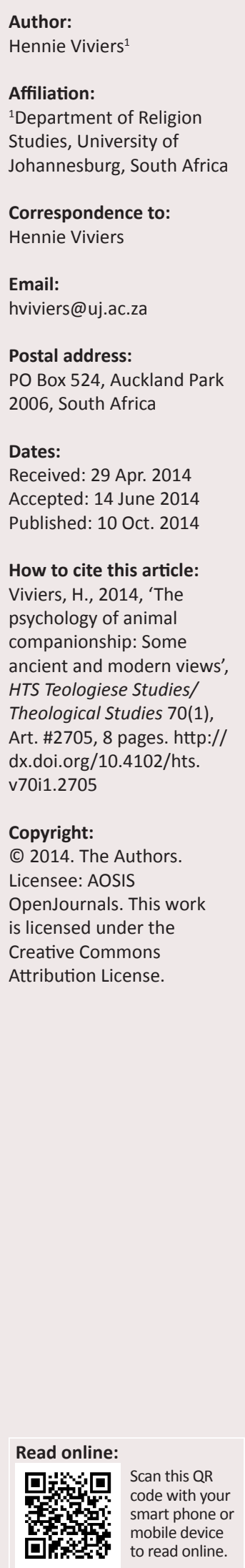

The intuitive sensing of a mental bond between ourselves and animals, especially those that live very close to us, our companion animals, has been there since early history. Some ancient Israelite views testify to an irresistible anthropomorphising of their domestic animals (Jn 3:5-9) as well as an acknowledgement of the socio-psychological support provided by them

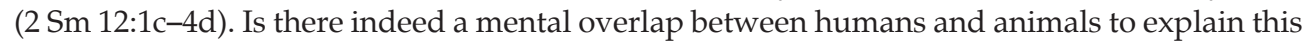
intuitive experiencing of a bond between ourselves and them since ancient times? Modern neuroscience, through neuro-imaging, has shown that dogs (at least) are able to reciprocate our thoughts and feelings, be it in a limited way. They seem to have some limited form of a 'theory of mind' previously ascribed to humans only. This explains why they have been humans' 'best friend' for the past 12000 years since they were domesticated from wolves. The intuitions of the ancients and the findings of modern science confirm that we and non-human animals all form intrinsically part of the fascinating web of life. This fact should sensitise us as moral agents to preserve this life.

\section{Introduction}

Companion animal owners are unanimous about what these animals mean to them: they enrich their lives in a variety of ways. Socio-psychological support is perhaps a good umbrella term to captivate what their companion animals provide them, obviously not excluding their physical well-being. Humans are convinced of a mental overlap with their animals as they discover something of themselves in them. They believe that their companion animals are able to match their feelings and sometimes even thoughts, since they have an intimate bond. ${ }^{1}$ This also explains why humans become so attached to their animals, that when they die it is not dissimilar to losing a close family member. Some veterinarians nowadays acknowledge this and sometimes even have some form of ritual if an animal has to be put down, to address the bereavement of the owners left behind. Strange as this may sound within traditional thought where the dichotomy between human and animal is emphasised, it can be supported in light of this contribution. Some would argue that this strong bond might be a result of our anthropomorphic imaginations of viewing animals incorrectly as humans. Actually animals are dumb and mindless, and only react positively to humans' outreach to gratify one or other instinctive urge.

There is, however, another viewpoint that concedes animals to be smart enough to return feelings and thoughts directed at them. De Waal (2010:37) describes an interesting experiment where a researcher wanted to measure empathy amongst very small children. The adult members of the household had to feign sadness and pain by sobbing, crying and choking. Small children of one year old were already able to comfort the 'distressed' family members. Amazingly, the household animals were just as worried as the small children by hovering around and putting their heads in the laps of the adults. Are animals really able to reciprocate our mental states? Is there a mental overlap between ourselves and them?

The aim of this contribution is to take a closer look at the psychology of human and domestic animal companionship. Why has this relationship been so close since early history? We know how humans 'think' and 'feel', but is our evolutionary (closer) kin, animals, able to meet and match our mental lives, even in a limited way? The first focus will be an appreciation of two exemplary ancient Israelite views on human and animal companionship, where the intuitive sensing of the bond between owners and their animals led to a spontaneous anthropomorphising of these animal companions and the accompanying emotional benefits for humans. I shall not elaborate on the moral of these two short narrations which had been debated ad nauseam. There is another moral 'between the lines' that the narrators refer to in passing and that is the ease (or

1.The human/animal bond $(\mathrm{HAB})$ is succinctly verbalised by the American Veterinary Medical Association as follows: " $[A]$ mutually beneficial and dynamic relationship between people and other animals that is influenced by behaviors that are essential to the health and well-being of both. This includes, but is not limited to, emotional, psychological, and physical interactions of people, other animals, and the environment' (Fine \& Beck 2010:7). 
accepted fact $)^{2}$ with which humans show their solidarity with their close animals. The second focus will be to test if there is any scientific ground to allow an anthropomorphising: to determine if we can speak of an animal 'mind' capable of communicating with ours (feeling and thinking), be it limited and non-verbal. Here some of the insights of especially cognitive psychology and neuroscience will be utilised in a very recent study carried out on dogs (Berns 2013).

\section{Ancient views and anthro- pomorphism: Two examples of animal companionship from the Hebrew Bible}

Two examples of how the ancient Israelites anthropomorphised domestic animals are taken from the books of Jonah and 2 Samuel. The story of the Nineveh inhabitants, both human and animal doing penance in Jonah 3:7-9, exemplifies the kind of personification that for our modern (scientific) taste might incline to 'bambification,' the sentimental over-ascribing of human characteristics to animals (see below). The keeping of a companion lamb by the poor man in the parable of 2 Samuel 12:1c-4d, likened to a 'daughter', comes across as more credible.

The post-exilic book of Jonah is an apt exercise in rhetorical persuasion (Trible 1994). As an illustrative story, akin to a parable, it exposes the narrow-minded ethnocentrism of Jonah, who represents a faction of Israel that was hoping that God would restore them to their glory of bygone days. That was when they ruled and worshipped exclusively with no place for others (e.g. heathen nations). Instead of this particularism, the story of Jonah wants to educate towards an inclusive universalism, accommodating not only former arch-enemies like the hateful Ninevites (the Assyrians) ${ }^{3}$ but the natural world as well (Simundson 2005:261). The latter is demonstrated by the Ninevite animals, cattle, sheep and goats that are spontaneously incorporated in the ritual of penitence decreed by the king in Jonah 3:

... Do not let any man or beast, herd or flock, taste anything; do not let them eat or drink. But let man and beast be covered with sackcloth. Let everyone call urgently on God ... (v. 7-8)

The Nineveh people surprisingly obeyed Jonah's one line sermon of doom and repented (v. 5), and the king followed suit. Construed as a chiasmus of striking contrasts the king, leaving his throne, ${ }^{4}$ removes his robe, putting on sackcloth and sitting in the dust or ashes (v. 6), overturning 'dwelling, dress, and dignity' (Trible 1994:183, 184). His decree of sackcloth and fasting for all in verse 7 is a 'cry' $\left(z^{\prime} q\right)$, echoing that of the sailors in chapter 1 . The decree is encompassing,

2.This is not to say that all in the Bible can nowadays be interpreted in an ecofriendly way. There are some eco- or bio-centric texts but the Bible's general, anthropocentric 'voice' is rather overwhelming.

3.Deist (1981:112) in an early popular work creatively draws an analogy between the meaning that Nineveh would have had for ancient Israel and that Auschwitz has for modern Jews.

4.The wordplay '... between mikkis'ô ('from his throne') and ... wayekas ('he covered') enhances the transformation ...' to sheer humility (Trible 1994:183). $h \bar{a}^{\prime} \bar{a} d \bar{a} m w^{e} h a b^{e} h e m \bar{a}$ [the human and the animal (merism)], and habāqār wehașs on [the herd and the flock (synecdoche)], should refrain from 'tasting' ${ }^{5}$, 'grazing' and drinking water (Sasson 1990:254; Trible 1994:185), and urgently $w^{e} j i q^{e} r^{e} \hat{u}$ [call] upon God. The latter and the final of the summoning instructions (all through exhorting jussives), to turn from evil and violence probably include only the humans, according to Van der Woude (1978:48). ${ }^{6}$ Even though inclining to the 'unrealistic' (but not a fable) in this story, perhaps even the ancients put some limit to their anthropomorphising of animals, having the hunch that the moral domain is proprietary to humans only. Both skilful formally and in regard to content, the narrator unwaveringly emphasises the intimate bond between humans and domestic animals.

Focusing on the (active in their own right) agency of nonhuman characters (mighty wind, the sea, the lots, the large fish, the animals of Nineveh, ${ }^{7}$ the plant, the worm, the east wind and the sun), Person (2008) argues a strong and convincing case that this ancient story is not only targeting ethnocentrism but anthropocentrism as well. He finds it strange that scholars only emphasise the role of humans in enhancing the plot of the story; for instance the tension line between the disobedience of Jonah and the obedience of the 'heathens', whilst non-human characters are part and parcel of this. The role of non-human characters cannot be restricted only to the satirical tone of the narrative. Person (2008:89) ascribes this to one-sided anthropocentric readings of the text. However, the question of anthropomorphism as such is not touched upon by Person, namely why did the ancients so readily personify their domestic animals? ${ }^{8}$ What prompted them to utilise poetic licence to personify animals in a parable-like story like Jonah (and more realistic deliberations), ${ }^{9}$ especially in this rather humorous, unrealistic depiction of mourning and fasting animals?

This story might be satirical and not that realistically credulous, but it must be noted that the 'real' use of animals in mourning rites throughout the ages is not that strange. Van der Woude says (1978:48): 'Voor het dragen van een rouwgewaad door dieren vgl Judith 4:10 en Herodotus 9, 24, waar gesproken wordt van het afscheren van paarden en lastdieren als teken van rouw.' In modern times in the Western world horses were 'commonly caparisoned in black' during funerals before the black motor car took their place (Allen 1976:224, fn. 23). And modern writers and poets in the same vein as their ancient

5.The verb 'taste' (tacam) is the same root as the noun "decree' and therefore constitutes another wordplay (Limburg 1993:82).

6. However, this summoning of animals to prayer would '... doubtless remind the audience of Joel's poetic interpretation of the cries of thirsty beasts as fervent prayers to God' (Allen 1976:225 on Jl 1:18-20; see also Simundson 2005:279).

7.See also the conferring of worth and value on them by God in the last verse of the book (Jn 4:11; Person 2008:87).

8.Sasson (1990:255) points out that in ancient Israel animals were kept for sacrifice and consumption and not as companion animals. However, to draw such a sharp
line between animals for use and for pleasure, is not correct as the example of line between animals for use and for pleasure, is not correct as the example of
the lamb as companion animal ( $2 \mathrm{Sm} \mathrm{12:1c-4d)} \mathrm{in} \mathrm{this} \mathrm{contribution} \mathrm{clearly} \mathrm{shows.}$ the lamb as companion animal ( $\mathrm{Sm} 12: 1 \mathrm{c}-4 \mathrm{~d}$ ) in this contribution clearly shows.
Limburg (1993:82) interestingly bases the solidarity or natural bond between Limburg (1993:82) interestingly bases the solidarity or natural bond between
humans and animals on the first creation story $(\mathrm{Gn} 1)$ where they were both created on the same (sixth) day.

9.See for instance Proverbs 6:6-8, 30:24-25 where the industrious ants are personified to become an inspiring teaching model for humans. 
counterparts seemingly cannot resist ascribing emotions to animals. The gifted and well-known South African poet, Antjie Krog, wrote a poem dedicated to Nelson Mandela shortly after his death in December 2013:

\section{... in Qunu the cattle refuse to leave the kraal \\ At Lusikisiki the fish lie close to the surface \\ In Mvuso the bustards make no sound ...}

Did the ancients perhaps intuitively sense some mental bond, for example sharing of emotions, between them and the animal world, especially their domestic animals whom they lived closely with? The text is silent on the 'why' of this personification, and one can only conjecture that our ancient forebears were 'aware' that animals (at least some, sometimes) were capable of behaviourally expressing feelings. The following example throws some more light on the fact that animals might be smarter than just dumb beasts.

The well-known parable of the poor man with his companion lamb that was stolen by the rich man, told by the prophet Nathan to expose David's 'stealing' of Batsheba from Uria, is another exercise in skilful storytelling. The parable proper in 2 Samuel 12:1c-4d, with a short introduction (Nathan's arrival), and an aftermath, David's judgement (v. 6), and Nathan's exposure of David (v. 7; attā ha' 'îs [you are the man!]), ${ }^{10}$ forms part of a larger narrative unit, namely chapter 11:27e: that is the conclusion of the wrong of David's adultery with Bathsheba and the link to the next chapter (12:1), Nathan's departure (12:15) (Fokkelman 1981:71). Fokkelman's narrative analysis of the parable is persuasive and an apt encapsulation of its impact. His structuring (and translation) is as follows:

1c Two men were in one city,

1d A rich $\operatorname{man}^{11}$ and a poor man.

2 The rich man had flocks and herds, very many

3a And the poor man had nothing except for one little ewe lamb which he had bought.

$3 b$ He raised it and it grew up together with him and his sons.

3c It ate of his bread, drank from his cup, and slept in his lap,

$3 d$ It was as a daughter to him.

4a A visitor came to the rich man.

$4 \mathrm{~b}$ He found it a pity to take any of his own flock or herd to prepare $^{12}$ for his guest.

4c He took the poor man's sheep away,

4d And prepared it for the man who had come to him. (Fokkelman 1981:72)

The parable is structured by way of a chiasmus, the opposite poles of 'rich' and 'poor' moving towards an '...everincreasing duality' (Fokkelman 1981:73). ${ }^{13}$ The last line of the

10.Goslinga (1962:214) humorously refers to this well-known expression from the Bible as '... geen "Donnerwort" (Schneider), maar wel een voltreffer, want hierop is David allerminst voorbereid.

11.This story character is a Nabal Redivivus (see $1 \mathrm{Sm} \mathrm{25)} \mathrm{according} \mathrm{to} \mathrm{Fokkelman}$ (1981:75).

12.The same word ( $/ a^{a} s \hat{s} t$ ) is used of Abraham preparing a calf for his guests ( $G n$ 18:7; Smith 1912:323).

13. Fokkelman (1981:73) motivates the chiastic structuring as follows: 'After the sequence rich-poor in one line (v. 1d) and the sequence rich-poor in two lines (v. 2 + v. 3a), we first hear three lines about the poor man (= portion 2) and finally four lines about the rich man (= portion 3 ). first portion, the buying ${ }^{14}$ of the lamb, prepares for the focus on the middle portion, of which 2 Samuel v. $3 \mathrm{c}$ forms the 'zenith' of the parable (Fokkelman 1981:74). The imperfect forms of the verbs, tōkal [it ate], tištē [it drank], and tiškab [it slept $]^{15}$ confirm the ongoing relationship between the poor man and his 'darling' (Herzberg 1964:312) lamb, fully part of his family as the 'daughter' ${ }^{\prime 16}$ amongst the sons. Formally and through the mental image it evokes, the centre scene portrays an atmosphere of warmth, care, safety and love, '... the mystical lustre of everyday life' (Fokkelman 1981:74). And David's emotional outburst of anger (not fitting for a judge) confirms this. It seems as if David probably saw more in this short tale than just sheep-stealing and wronging of the poor man, but destroying his 'family' as well; has he sympathy for the lamb also? Therefore his forceful 'onnodig eedsweren' (Goslinga 1962:213) and even haj jehwh kî bên māwêt [death sentence], ironically to become his own, apart from the according-to-law (Ex 22:1) fourfold recompense required at the time (Mauchline 1971:253). The shock of the sacrificed, innocent little ewe lamb, nothing less than a loving 'daughter', encapsulates the intimate emotional bond between a human and a companion animal.

Although the detail of the buying of the little ewe lamb by this poor man is not spelled out, the openness of the text allows that he probably obtained her for next to nothing, because nobody else wanted her. This, together with his raising of the lamb, wajehajjêha [let it live], reminds one how many people also nowadays acquire their companion animals from shelters or elsewhere, giving them a new home. The personification of the lamb is conspicuous and intensifies; she grew up, ate, and drank with the family, and lastly, slept intimately in her owner's lap. The final worth being conferred onto her is by calling her explicitly a 'daughter', effectively binding this homely scene together by way of an inclusio with the (real) sons. The lamb does what most companion animals do for their owners; providing them with socio-psychological support (see more detail below). She enhances sociality between the family members, provides an opportunity for humans to show nurturance and love which makes them feel good, and she gives emotional support and esteem specifically to her owner: if nobody else loves or respects this poor man at least the 'loving' lamb acknowledges him. This probably also explains the abundance of companion lambs in poor houses in Syria (Smith 1912:322) and other companion animals across the world. That the lamb reciprocates appropriately to what is done to her (eat what she is fed, drink what she is offered and positively responding to being picked up and nurtured) is implied, otherwise this intimate relationship between her and her human family would not have been possible. The question is, does she only reciprocate instinctively like a stimulus-response machine wanting food and safety, or is she able to reciprocate 'emotionally'

14. Note the alliteration and rhyme (assonance) between the words $q^{e} t a n n \bar{a}, q \bar{a} n \bar{a}$ and kibsā (Fokkelman 1981:73).

15.The whole sentence in Hebrew is a succinct display of a unified rhythm, alliteration and assonance: mippittō tōkal / umikkōsō tišté / ubehēqō tiškab (Fokkelman 1981:74).

16.The Hebrew for 'daughter' (bat) clearly reminds of Batsheba (Campbell 2005:116; Fokkelman 1981:79). 
and 'thinking', be it limited and in a 'lambish' way to meet and match the mental outreach from humans? Are animals perhaps smarter than just dumb beasts?

\section{Modern scientific views and anthropomorphism: Can animals 'feel' and 'think'?}

Daston and Mitman (2005:1-6) eloquently describe anthropomorphism as an 'irresistible taboo.' The intuitive, almost compulsive human assumption of '.. a community of thought and feeling between themselves and a surprising wide array of animals ...' (Daston \& Mitman 2005:2) has just been illustrated from the two ancient Israelite examples. This 'irresistibility' to personify or to interpret our reality through a human lens encompasses more than just living things like animals, but also our inanimate world (Guthrie 1993:124). And it happens not only in the pre-scientific world of everyday living but in science as well. It is especially in scientific circles where anthropomorphism is regarded as a 'taboo'17, but seemingly unavoidable. Therefore molecules are described as left- or right-handed, stars are born and die (Guthrie 1993:166-167) and nature becomes a selecting 'person' in the process of evolution (Charles Darwin). Serpell (2005:123), undecided whether anthropomorphism is a useful heuristic tool in ethology, nevertheless acknowledges it as a fact, indeed a transformative force (see below). Siegel adds that it can illuminate science rather than fabricate it (2005:199, 221, following primatologist Anne Russon and H. Lyn Miles).

One can understand the denial of behaviourists of any anthropomorphic traits in animals, markedly so in their strong reaction against a so-called anthropocentric anthropomorphism. The latter is the sentimentalist, popular humanisations aptly described by Frans de Waal (2001:71) as 'bambification'. We often see this portrayed in animal cartoon films - the well-known big-eyed, gentle little deer almost entirely humanlike in its speaking, thinking and feeling. De Waal rejects this but at the same time, however, warns against (behaviourist) anthropodenial as if an unbridgeable dualism exists between humans and animals. This view cannot be substantiated either in the light of evolutionary evidence. Instead of an anthropocentric anthropomorphism he pleads for an animalcentric anthropomorphism: that is, an animal should be understood in its own right (De Waal 2001:77). This is perhaps easier said than done, keeping in mind that humans do not really know what animals think because they cannot talk to us (Daston \& Mitman 2005:3; Hauser 2006:336, 341).

Speaking of the 'thinking' of animals, it is somewhat of an open question whether they have a 'theory of mind' as humans do. Humans' introspective experiences allow them to develop self-awareness, to become aware of an own mind ${ }^{18}$

17. Originally the word referred to the attribution of human form to gods, forbidden by several religions as blasphemous' (Daston \& Mitman 2005:2).

18.The 'mind' is not empirically verifiable but as we study behaviour we conclude to its existence as the conducting, operating 'phenomenon' behind our thoughts and actions (Barrett 2004:95). and to easily conclude to other humans having minds also. It applies to animals as well: that they also have minds satisfies our (human) intuitive feelings (Barrett 2004:101, 103). But do animals really have minds, and are they able to mindread and intelligently construct a 'theory' of someone else's thoughts, feelings, desires and convictions as humans constantly do through empathetic perspective taking? Is this 'extreme form of anthropomorphism' (Serpell 2005:122) applicable to animals also, seeing that it has for so long been regarded as unique and proprietary to humans only? It is interesting that as research in ethology progresses, the ascription of this mental tool, or some form of it, to more and more animals is increasing. This applies to some big-brain animals (e.g. chimpanzees ${ }^{19}$ and other apes, elephants, dolphins, etc.; and perhaps also some highly intelligent bird species) that show self-consciousness (Serpell 2005:123). ${ }^{20}$ In what follows below on the 'thinking' of dogs, humans' 'best friend' is added to this list when Gregory Berns (2013:184) concludes to a 'dog theory of mind'. It is time to firstly take a closer look at how and what humans think about their companion animals, humanising them as if they are fellow human beings (Serpell 2005:127). Secondly, and flowing from the first, the focus will also be on companion animals' reciprocity, what they might 'think' of and 'feel' towards their owners (Berns 2013).

Dogs are probably the favourite companion animal across the world. They make up approximately one tenth of the total human population $( \pm 700000000)$. Canis lupus [wolf] was tamed and domesticated into Canis familiaris [dog] about 12000 years ago at the beginning of the agricultural era, and was the first animal to be domesticated from its wild ancestors (CluttonBrock 1995). Although dogs come from wolves they are not wolves anymore. They were selected for taming and training and evolved through the process of neoteny '... whereby an animal retains its youthful character as an adult ...', which allows easy learning even into adulthood (Coppinger \& Schneider 1995:38). Dogs were domesticated and consumed as a source of food up until today in some Eastern cultures. They assisted humans as very efficient hunting partners: for example the iKung San of the Kgalagadi (Clutton-Brock 1995:14), and generally became faithful companions to humans living in close proximity with them. Most dogs today across the world are village dogs, living either on the edges of human societies or closer (Boitani et al. 1995) and featuring in a wide variety of roles. One of these roles is scavenging as 'garbage collectors,' which more or less fits the rather inferior, often despicable, status that they, along with pigs, had in biblical times (see $\mathrm{Pr}$ 26:11; 2 Pet 2:22).

Compared to their wolf ancestors, dogs are puppy-like, which make them naturally receptive for training ${ }^{21}$ also

19.De Waal (2006:72) concludes as follows: 'I am personally convinced that apes take another's perspective ...'.

20.Serpell (2005:123) argues that the roots of anthropomorphism lie in 'the human capacity for so-called reflexive consciousness ... self-knowledge ...'. If I have a mind I intuitively assume that others have minds also (see Barrett 2004:95-105).

21.Note also how the development of dogs through different stages is described anthropomorphically: 'A pup passes through several stages of receptivity when it is biologically and psychologically [my emphasis] ready to learn a particular it is biologically and psychologically [my emphasis] ready to learn a particular
behaviour' (Coppinger \& Schneider 1995:27). Puppies are also '... vulnerable to psychological injury' (Serpell \& Jagoe 1995:98). 
into adulthood. They look like juveniles (e.g. broad 'brachycephalic' heads, short-nosed, upturned tales, etc.) and elicit the 'cute response' (Serpell 2005:124), that is, humans' intuitive loving or caring outreach towards them as if they were child surrogates. They also act like juveniles: they 'look up' to their owners for guidance, sit and wait for their food, 'love' their owners, panic when their (human) parents are not around, and so on (Coppinger \& Schneider 1995:40). These characteristics have indeed made them humans' best friend, so much so that almost $75 \%$ of dog (and other companion animal) owners regard them as akin to their children and can rely more on them than their own human family members. They are treated as if they are fellow 'humans' because they respond and meet their owners' expectations of close companionship. This they do by reciprocating their owners' physical and psychological needs and experiences.

Physically dogs contribute to the health of their owners. Children's ${ }^{22}$ blood pressure drops when a dog enters the room, and adults who own dogs benefit likewise by having reduced risk factors for cardiovascular disease and strokes (high blood pressure, serum triglycerides and cholesterol). They also show better improvement after heart attacks when compared to non-owners (Hart 1995:170; Serpell 2005:125). ${ }^{23}$ Amazingly, dogs are so adjusted and attached to their human companions that when in their presence their blood pressure drops as well and they even develop diarrhoea, gastric upsets and epileptic seizures in reaction to anxiety and stress in their human family (Hart 1995:163, 170). Somatic benefits go hand in hand with socio-psychological well-being. ${ }^{24}$ Serpell (2005:125-126) indicates five terrains where companion animals enhance humans' happiness.

Firstly, they give us emotional support. If nobody else loves us, cares for us or shows us friendship, they will: but are they really able to? As with their physical reciprocation, dogs also match the emotionality of their human owners. They show signs of separation anxiety, just like small children, when left alone for long periods by their owners. ${ }^{25}$ Secondly, they enhance social integration. The elderly, people in wheelchairs or those who use service dogs, for example the blind, spontaneously attract the attention of others when their dogs accompany them, and the consequential mutuality and socialisation almost recreate a family atmosphere (Hart 1995:168). Thirdly, part of socialisation is receiving esteem: your dog facilitates your acknowledgement and recognition by others. Furthermore, if nobody else does it, a dog constantly lets its owner feel like Napoleon (Serpell 1989:126 referring to Aldous Huxley). Practical, instrumental or informational support is a fourth terrain where companion animals can provide assistance, for example working or

22.Children benefit most in terms of their overall health (Berns 2013:53). Added to this is the field of children's education that lies wide open to teach them a proper ethic of care towards our non-human 'kind', and animal world in general.

23.Serpell (2005:126) adds 'rheumatic fever, diabetes, nephritis, pneumonia, and most forms of cancer, as well as depression and suicide.'

24.Fine and Beck (2010:7) refers to the view of medical oncologist Edward Creegan, who is convinced that the 'mind/body connection is anchored by our pets.'

25.This is a consequence of their evolved juvenility, making them over-dependent (Serpell 2005:130) service dogs without which their owners would be almost forlorn. A last terrain is where companion animals provide opportunities for nurturance and protection which let us feel wanted: 'For both children and elderly adults ... care for an animal may have value in giving the person an experience of mattering to another' (Hart 1995:169).

Apart from the few examples mentioned already, animalassisted interventions (AAI) are increasingly being used and appreciated within health environments, both physical and psychological. Animal-assisted therapy (AAT) has proven valuable in the lives of people in 'transition', like divorcees, newlyweds, those who have lost loved ones, and the elderly (Fine \& Beck 2010:9). The same applies to animal-assisted activities (AAA) in, for instance, homes for disabled children and for the aged. A word of caution is, however, also necessary. Even though one is tempted to believe that studies on AAI, AAT and AAA are unanimous in contributing holistically to human health and well-being, this is not so. There are studies that are inconsistent with our positive expectations of the bond between humans and animals (Friedmann, Son \& Tsai 2010; Katcher \& Beck 2010:50). Researchers are, however, working hard to refine their methodologies towards more substantiated consistency within these fields (Fine 2010).

In the long history of the relationship between humans and dogs, the latter not only benefited human well-being, but they in turn reaped survival benefits. Domestic dogs, and other domestic animals, outnumber their wild counterparts by far. Serpell (2005:128) states that anthropomorphism has directly contributed to this boom in numbers. It is the humanly irresistible favouring of infantile characteristics and behaviour that has led to the great diversity of dog races and numbers all over the world. However, these 'puppies' that were created in the image of (childlike) humans, expose a downside as well, in spite of tremendous breeding successes. Serpell (2005:132) speaks of hybrid monsters that we have created, that have been physically and mentally (see fn. 25) deformed to meet our needs. For example, an English bulldog might look cute but it is a 'train wreck' physically with its 'severely brachycephalic head, prognathous upcurved mandibles, distorted ears and tail, stunted limbs, and ungainly movements' (Serpell 2005:129), with accompanying breathing and many other health problems. But in spite of this, the mutual benefit between human and dog is a fact. Humans humanise and treat them as if they are fellow humans. Humans perceive them as mentally overlapping with themselves, and they in turn reciprocate appropriately to match humans' needs. The question, however, remains: is there more to their response to this relationship than perhaps just instinctive animal gratification? Or are they able to react on a 'higher' level, and perhaps 'love' and 'think' in a way that comes close to that of humans?

To address the problem that animals cannot talk to us and tell us what they feel and think, a neuroscientist, Gregory Berns (2013:xiii), set himself the task to find out what goes on in their minds. This he did in a very innovative way by doing a functional magnetic resonance imaging (fMRI) 
scan on dogs, the first in the world that he was aware of. Functional magnetic resonance imaging done on humans provides insight into the 'black box' of the brain-mind. Very aware of the criticism against neuro-imaging as a new science still in its infancy and with often naive conclusions, jumping from brain activity directly to complex behaviour (Berns 2013:155-157; Fine 2011), he and his team accepted the challenge to scan a dog's brain. The biggest challenge was to condition the dog to sit very still in the scanner tube (instead of lying like a human) to be able to succeed in measuring the 'firing' of the brain. His dog, Callie (a terrier mix), and McKenzie (a Border collie), belonging to a colleague, were the first two guinea-pigs of this groundbreaking experiment.

An important assumption guiding the experiment was that humans and mammals share the same kind of brain, to create a functional homology (Berns 2013:19). ${ }^{26}$ Berns (2013:111), following psychobiologist Kent Berridge, distinguishes between the so-called primitive or reptilian brain (the basal ganglia), the paleomammalian brain (the limbic system) and the neomammalian brain (the neo-cortex). The latter is conspicuously recognised through the large frontal lobes in humans, the 'seat' of symbolic, abstract and rational thought, including our capacity to construct a 'theory of mind,' that distinguishes us from animals. In dogs the frontal lobes are rather small, which predicts rather simpler 'theory of mind' abilities. However, the olfactory bulb ('a rocket in a socket') is massive, giving them a sense of smell that exceeds ours by an incredible 100000 times (Berns 2013:154, 196). The basal ganglia and limbic systems associated with positive emotions are almost the same in humans and dogs (Berns 2013:112,156), and the caudate nucleus that forms part of the basal ganglia, accommodates the so-called reward system. In humans the caudate 'fires' when predicting rewards: simply put, after some meaningful interpreting (thinking) has happened, a state of heightened anticipation follows and then the experiencing of positive emotions (Berns 2013:183). If the same happens with a dog's caudate as with humans, then it would prove that dogs are also capable of 'thinking' and 'feeling', even returning 'love' (Berns 2013:157). Importantly though, the stimulation of the dog caudate by food only would be meaningless and show just an instinctive reaction. The interpretation of the hand signals (which convey a great deal of information other than just a Pavlovian ringing bell) that Berns and his team developed and which precedes the food, however, points to social learning. ${ }^{27}$ By looking at the hand signals the dog is creating a theory of what the human is intending: a 'dog theory of mind' (Berns 2013:183-184).

Berns and his team went through a long, tiresome and often humorous training process to make their experimental dogs experiment- and scanner-wise, but at long last they obtained their scans. It is also quite interesting that they initially made

26.Darwin, in whose time brain science hardly existed, nevertheless had great insight into similar kinds of emotional expression (e.g. fear, rage, joy) between humans was more interested in the evolution of emotions (from animals to humans) and was more interested in the evolution of emotions (from anin
not the emotions of animals as such (Berns 2013:33,110).

27. Reaction to a 'Pavlovian ringing bell' (or something similar) points to associative learning, much closer to the instinctive pole of behaviour. the mistake of personifying the dog to think like a human. ${ }^{28}$ Hand signals and the accompanying feeding of peas and hot dogs (the food choices for the experiment) to stimulate the caudate, should make a difference if the preferred hot dogs came first according to Berns' human thinking. However, the dog just cared whether food was coming, irrespective of the order (Berns 2013:158-167).

Caudate activation confirmed the dog's mental-emotional reciprocation, a positive emotional and non-verbal thank you!' (to humanise somehow) after the dog 'read and interpreted' the hand signals leading to food. But a dog reciprocates more! In the area just above the caudate there are mirror neurons, the kind of neurons that activate our empathetic (involuntary) copying of another's behaviour: you smile and I do likewise. The lighting up of these neurons as well indicated a 'mirroring' of the hand signals of the human that the animal seemed to map onto its paws, the same as when a dog licks its chops when watching humans eat (Berns 2013:192). This points to some kind of internal mental model that the dog was constructing. After a further smell experiment where Callie, Berns' dog, was exposed to the familiar smell of his wife, the caudate 'lit up' as expected to portray positive emotion. However, another area was activated, namely the inferior temporal lobe, a region closely associated with memory, remembering a previous hand signal or most probably his wife. Along with activity also in the motor cortex, all these regions together pointing towards a theory of mind, showing that the dogs might be constructing mental models of the researchers' actions. Similar to the way humans use memories and ascribe meaning to people and actions all the time, so it seems do dogs (Berns 2013:209). Berns notes dogs have been previously ascribed a 'theory of behaviour' (they learn that certain behaviours lead to certain outcomes), but his findings now show them to also have a 'theory of mind' (ToM):

... even if dogs have only a rudimentary ToM, that would mean dogs are not just Pavlovian stimulus-response machines. It would mean that dogs might have the same level of consciousness as a young child. (Berns 2013:173,174)

Dogs have a high degree of social and emotional intelligence not only towards their own kind, as can be expected, but towards humans also. By watching us closely and constantly ${ }^{29}$ they are able to empathise (Berns 2013:229) and 'think', which is also Berns' grand conclusion to his study on dogs: '[T]hey're thinking what we're thinking' (Berns 2013:226), be it in a limited way. They reciprocate our thoughts and feelings, and it is therefore not that far-fetched when a dog owner says: 'My dog really understands me!' No wonder this animal has been the 'first friend' (Berns 2013:226) of humans for so many millennia.

28. Human language provides another good example as we intuitively ascribe the same informational communication strategies to animals, whereas their body signalling and sounds most probably have more to do with manipulating the other party than conveying propositional information (Dawkins \& Krebbs 1978).

29.Berns humorously remarks that dogs might probably think that humans talk too much to get them to do things, as they precisely know what we want (having 'mind-read' us) long before we give them explicit verbal or non-verbal signals. 
The scanning of live, healthy and 'awake' animal brains in general (acknowledging the challenges that each unique animal requires to do this), as Berns and his team have done with dogs, promises some fascinating results of possible animal 'thinking' and 'feeling' for the future. It is a pity that they only scanned a dead lamb's brain to match the size of a dog's, in preparation of the exact settings of the scanner. A scan of a live, trained lamb could have highlighted the possible 'smartness' 30 also of the companion lamb in our example above. Ancient human intuition of the positive bond between them and their domestic animals acknowledged their worth. Modern science has confirmed that animals are certainly not dumb brutes and mentally (intelligently) overlap to some extent with humans, even if only in a limited manner. Human and non-human animals both form part of the fascinating web of life, and this should alert us to view the animal world with far greater sensitivity than has been the case.

\section{Conclusion}

Animals are indeed smarter than we used to think previously, being strongly influenced by the behaviourist viewpoint that they are only stimulus-response machines, being driven by their basic instincts. They are able to show emotion and construct mental models of their world, and some animals, for example dogs, are even able to meet and match humans' thinking and feeling. Their reciprocation is obviously limited and cannot reach the heights of the symbolic, abstract and rational thought that we are capable of. However, even though we left the animal world behind in our own evolution, there is a mental overlap between us and them, making meaningful communication possible. When we experience this, especially with our close companion animals, it confirms the evolutionary bond that we share, being all part of the fascinating web of life. This fact should sensitise us as moral agents to preserve this life. Neuroscience, for example fMRI, applied to animals, as Berns has begun doing on dogs, holds good promise for looking also into the 'black box' of the animal brain-mind and how it impacts on their relationship with humans. The fields of animal-assisted intervention, therapy and activities (AAI, AAT, AAA) are being appreciated more and more. With regard to humans, with science still in progress, Fine and Beck (2010:12) remark succinctly: 'They live the miracles that the scientific and clinical communities would like to harness and understand better.'

We should not only appreciate what science has laid bare lately, but also the intuitive responses of our ancient forebears. It seems that they also were smarter than we often think, by experiencing a deep-seated bond with their companion animals. Their pre-scientific expressions of their views of 'thinking' and 'feeling' with their animals were done by way of touching and persuasive narratives. They experienced the same socio-psychological support given by

30.Sheep are good at (individual) face recognition through their face recognition system. It has emotional significance allowing them to keep company with their own kind and avoid their enemies. They are also able to mentally rotate images from front to profile in order to match a front view with a profile one (Reznikova 2007:366-367). Perhaps we should rethink the popular conviction that sheep are dumb. their animal companions as we moderns do, and irresistibly anthropomorphised them as we, including scientists, do today to enhance our understanding.

\section{Acknowledgements Competing interests}

The author declares that he has no financial or personal relationship(s) that may have inappropriately influenced him in writing this article.

\section{References}

Allen, L.C., 1976, The New International Commentary of the Old Testament: The books of Joel, Obadja, Jonah and Micah, WB Eerdmans, Grand Rapids.

Barrett, J.L., 2004, Cognitive Science of Religion Series: Why would anyone believe in God? AltaMira, Walnut Creek.

Berns, G., 2013, How dogs love us: A neuroscientist and his adopted dog decode the canine brain, New Harvest, Boston.

Boitani, L., Francisci, F., Ciucci, P.\&Andreoli, G., 1995, 'Population biology and ecology of feral dogs in central Italy,' in J. Serpell (ed.), The domestic dog: Its evolution, behaviour and interactions with people, pp. 217-244, Cambridge University Press, Cambridge.

Campbell, A.F. (S.J.), 2005, Forms of Old Testament literature VIII: 2 Samuel, WB Eerdmans, Grand Rapids.

Clutton-Brock, J., 1995, 'Origins of the dog: Domestication and early history', in J. Serpell (ed.), The domestic dog: Its evolution, behaviour and interactions with people, pp. 7-20, Cambridge University Press, Cambridge.

Coppinger, R. \& Schneider, R., 1995, 'Evolution of working dogs,' in J. Serpell (ed.), The domestic dog: Its evolution, behaviour and interactions with people, pp. 21-47, Cambridge University Press, Cambridge.

Daston, L. \& Mitman, G., 2005, 'Introduction,' in L. Daston \& G. Mitman (eds.), Thinking with animals: New perspectives on anthropomorphism, pp. 1-14, Columbia University Press, New York.

Dawkins, R. \& Krebbs, J.R., 1978, 'Animal signals: Information or manipulation?' in J.R. Krebs \& N.B. Davies (eds.), Behavioural ecology: An evolutionary approach, pp. 282-309, Blackwell Scientific Publications, Oxford.

Deist, F., 1981, Die God van Jona, Tafelberg-Uitgewers, Kaapstad.

De Waal, F.B.M., 2001, The ape and the Sushi master: Cultural reflections of a primatologist, Basic Books, New York.

De Waal, F.B.M., 2006, Primates and philosophers: How morality evolved, Princeton University Press, Princeton.

De Waal, F.B.M., 2010, 'Morality and its relation to primate social instincts,' in H. Høgh-Olesun (ed.), Human morality \& sociality: Evolutionary \& comparative perspectives, pp. 31-57, Palgrave Macmillan, New York.

Fine, A.H. (ed.), 2010, Handbook on animal-assisted therapy: Theoretical foundations and guidelines for practice, 3rd edn., Academic Press (Elsevier), Amsterdam.

Fine, A.H. \& Beck, A., 2010, 'Understanding our kinship with animals: Input for health care professionals interested in the human/animal bond,' in A.H. Fine (ed.), Handbook on animal-assisted therapy: Theoretical foundations and guidelines for practice, pp. 3-15, Academic Press (Elsevier), Amsterdam.

Fine, C., 2011, Delusions of gender, Icon Books, London.

Friedmann, E., Son, H. \& Tsai, C., 2010, 'The animal/human bond: Health and wellness,' in A.H. Fine (ed.), Handbook on animal-assisted therapy: Theoretical foundations and guidelines for practice, pp. 85-95, Academic Press (Elsevier), Amsterdam.

Fokkelman, J.P., 1981, Studia Semitica Neerlandica: Narrative art and poetry in the books of Samuel: A full interpretation based on stylistic and structural analyses, volume 1 King David (II Sam. 9-20 \& I Kings 1-2), Van Gorcum, Assen.

Goslinga, C.J., 1962, Commentaar op het Oude Testament: Het tweede boek Samuël, JH Kok, Kampen.

Guthrie, S.E., 1993, Faces in the clouds: A new theory of religion, Oxford University Press, Oxford.

Hart, L.A., 1995, 'Dogs as human companions: A review of the relationship,' in J. Serpell (ed.), The domestic dog: Its evolution, behaviour and interactions with people, pp. 161-178, Cambridge University Press, Cambridge.

Hauser, M.D., 2006, Moral minds: How nature designed our universal sense of right and wrong, HarperCollins, New York.

Herzberg, H.W., 1964, Old Testament library: I \& II Samuel: A commentary, SCM, London.

Katcher, A.H. \& Beck, A.M., 2010, 'Newer and older perspectives on the therapeutic effects of animals and nature,' in A.H. Fine (ed.), Handbook on animal-assisted therapy: Theoretical foundations and guidelines for practice, pp. 49-58, Academic Press (Elsevier), Amsterdam.

Krog, A., 2013, 'Sunday Read: Antjie Krog's Poem, "Lament at the Death of Mandela"' in, Books LIVE, viewed on 28 April 2014, from http://bookslive.co.za/ blog/2013/12/15/sunday-read-antjie-krogs-poem-lament-at-the-death-ofmandela/ 
Limburg, J., 1993, Old Testament library: Jonah: A commentary, SCM, London.

Mauchline, J., 1971, New Century Bible: 1 and 2 Samuel, Oliphants, London.

Person, R.F. Jr., 2008, SBL Symposium Series: 'The role of non-human characters in Jonah,' in N.C. Habel \& P. Trudinger (eds.), Exploring ecological hermeneutics, pp. 85-90, SBL, Atlanta.

Reznikova, Z., 2007, Animal intelligence: From individual to social cognition, Cambridge University Press, Cambridge.

Sasson, J.M., 1990, Anchor Bible 24B: Jonah: A new translation with introduction, commentary, and interpretation, Doubleday, New York.

Serpell, J., 1989, 'Humans, animals, and the limits of friendship,' in R. Porter \& S. Tomaselli (eds.), The dialectics of friendship, pp. 111-129, Routledge, London.

Serpell, J., 2005, 'People in disguise: Anthropomorphism and the human-pet relationship,' in L. Daston \& G. Mitman (eds.), Thinking with animals: New perspectives on anthropomorphism, pp.122-136, Columbia University Press, New York.
Serpell, J. \& Jagoe, J.A., 1995, 'Early experience and the development of behaviour,' in J. Serpell (ed.), The domestic dog: Its evolution, behaviour and interactions with people, pp. 79-102, Cambridge University Press, Cambridge.

Siegel, S., 2005, 'Reflections on anthropomorphism in The Disenchanted Forest', in L. Daston \& G. Mitman (eds.), Thinking with animals: New perspectives on anthropomorphism, pp.196-222, Columbia University Press, New York.

Simundson, D.J., 2005, Abingdon Old Testament Commentaries: Hosea, Joel, Amos, Obadiah, Jonah, Mica, Abingdon Press, Nashville.

Smith, H.P., 1912, International critical commentary: A critical and exegetical commentary on the books of Samuel, T\& T Clark, Edinburgh.

Trible, P., 1994, Guides to Biblical scholarship, Old Testament series: Rhetorical criticism: Context, method and the book of Jonah, Fortress Press, Minneapolis.

Van der Woude, A.S., 1978, De Prediking van het Oude Testament: Jona, Nahum, GF Callenbach, Nijkerk. 